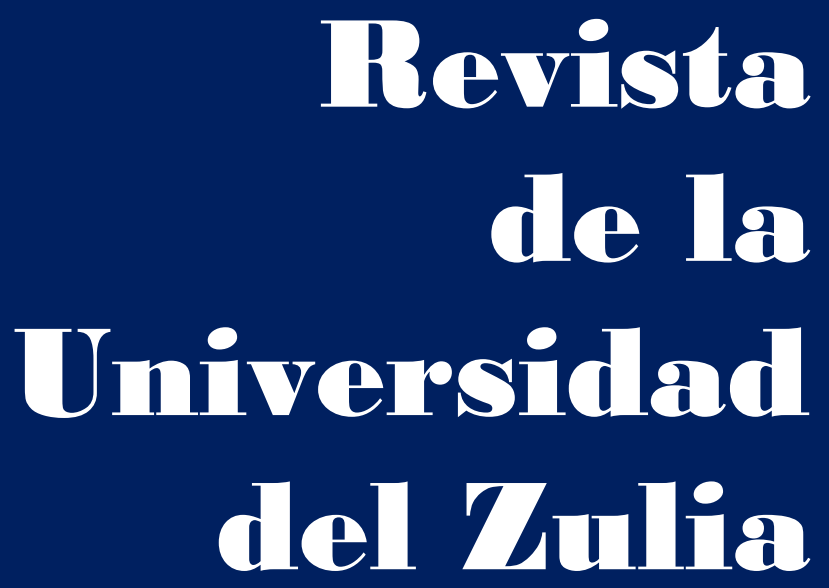

Fundada en 1947

por el Dr. Jesús Enrique Lossada

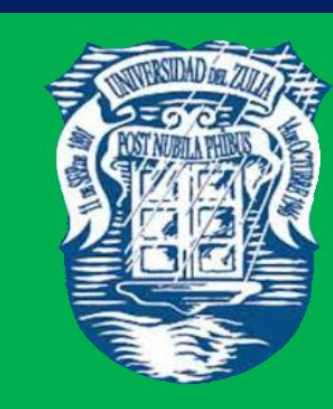

Ciencias del

Agrad,

Ingemiería

y Tecinología

\section{Aกัต 13 No $\mathbf{3 6}$} Enero - Abril 2022

Tercera Épaca

Maracailbo-Venezuela 
REVISTA DE LA UNIVERSIDAD DEL ZULIA. $3^{\text {a }}$ época. Año $13 \mathrm{~N}^{\circ}$ 36, 2022

D. P. Guerrero-Cuasapaz et al. // Analysis of the structural behavior of flat and circular ... 222-240

DOI: http://dx.doi.org/10.46925//rdluz.36.15

\title{
Analysis of the structural behavior of flat and circular self-supporting roof using finite elements
}

\author{
David Patricio Guerrero-Cuasapaz* \\ Milton Bolívar Guerrón-Figueroa ** \\ José Luis Pilamunga-Guallpa*** \\ Cristhian Daniel Páez-Redrován**** \\ Nelson Andrés López-Machado*****
}

ABSTRACT The development and innovation of Science, specifically in the branch of construction in Civil engineering, has led the implementation of new alternatives in analysis, design and construction of industrial buildings. For this reason, in this research it was proposed to carry out a study of structural behavior of two types of self-supporting roofs: flat and circular, which were analyzed using computational tools for simulation through finite elements, in which initially the structure made up of columns, beams and steel sheets was completely modeled with an equivalent cross section, which made up the self-supporting roofs; then only the steel sheets with real cross section were discretized, and it was noted that in the extremes were the greatest stresses generated by the application of horizontal and vertical loads; and the maximum displacement of the circular roof was $14.32 \%$ of the flat one.

KEYWORDS: Construction engineering; structural design; self-supporting roof; weight.

*Professor. Civil Engineering Department, Salesian Polytechnic University. Quito, Ecuador. ORCID: https://orcid.org/0000-0002-8547-906X. E-mail: dguerrero@ups.edu.ec

**Professor. Civil Engineering Department, Salesian Polytechnic University. Quito, Ecuador. ORCID: https://orcid.org/0000-0002-4136-9483

***Professor. Civil Engineering Department, Salesian Polytechnic University. Quito, Ecuador. ORCID: https://orcid.org/0000-0002-0892-1838

****Professor. Civil Engineering Department, Salesian Polytechnic University. Quito, Ecuador. ORCID: https://orcid.org/0000-0001-5633-6855

*****Professor. Structural and Geotechnical Engineering Department, Pontifical Catholic University of Chile. Santiago, Chile. ORCID: https://orcid.org/0000-0002-3111-7952

Recibido: 05/10/2021

Aceptado: 01/12/2021 
REVISTA DE LA UNIVERSIDAD DEL ZULIA. 3época. Año 13 Nº 36, 2022 D. P. Guerrero-Cuasapaz et al. // Analysis of the structural behavior of flat and circular ... 222-240

DOI: http://dx.doi.org/10.46925//rdluz.36.15

\section{Análisis del comportamiento estructural de cubierta autoportante plana y circular utilizando elementos finitos}

RESUMEN El desarrollo e innovación de la Ciencia y específicamente dentro la rama de la construcción en Ingeniería civil ha provocado que se implementen nuevas alternativas en análisis, diseño y construcción de naves industriales. Por tal motivo, en la presente investigación se planteó realizar un estudio del comportamiento estructural de dos tipos de cubiertas autoportantes: plana y circular, las mismas que fueron analizadas utilizando herramientas computacionales para simulación a través de elementos finitos, en las que inicialmente se modeló de forma completa a la estructura constituida de columnas, vigas y láminas de acero con una sección transversal equivalente, que conformaron las cubiertas autoportantes; posterior a ello se discretizó únicamente las láminas de acero con sección transversal real, y se observó que en los extremos fueron los mayores esfuerzos generados por la aplicación de solicitaciones horizontales y verticales; y el desplazamiento máximo de la cubierta circular fue $14.32 \%$ de la plana.

PALABRAS CLAVE: Ingeniería de la construcción; diseño estructural; cubierta autoportante; peso.

Introduction

Innovation and competitiveness in the world of construction causes the manufacture of roofs for industrial buildings to change both in their materials and their geometry. The most used materials for the construction of sheds are wood, aluminum, and steel, which easily adapt to various environments or climates without losing their functionality (Soria, 2020).

Industrial buildings made of structural steel provide qualities such as versatility, implementation of new facilities, extensions, and improvements in general. Besides, this type of structure can be designed in a plastic range in order to reduce manufacturing costs (Arnedo, 2016).

Currently, industrial buildings use self-supporting roofs which are an enclosure or membrane-type roof that uniformly distributes the stresses received, either thermal or climatic of any order, and distributes them on the walls in a uniform way, contributing to the distribution of loads and their linear and uniform transmission to the foundations. As there is no supporting structure, the roofs rest on the load-bearing beams or perimeter beams, which constitutes their 
REVISTA DE LA UNIVERSIDAD DEL ZULIA. 3época. Año $13 \mathrm{~N}^{\circ}$ 36, 2022 D. P. Guerrero-Cuasapaz et al. // Analysis of the structural behavior of flat and circular ... 222-240 DOI: http://dx.doi.org/10.46925//rdluz.36.15

main differential element: the total absence of purlins, trusses, beams, or any other intermediate resistant element. These are works in which the calculation of the geometry of the structure must be carried out with accuracy since it is not a system based on standard pieces but it is manufactured and custom-made for each building, allowing to incorporate elements such as isolations, translucent, which can be curved or flat (Durma, 2016).

In Ecuador, the analysis and design of industrial buildings have been pivotal for the implementation of several projects on a national scale (Cuichán, 2016), which promote and make the country's productive system grow; for this reason, there is a need to know the structural behavior between a flat and circular self-supporting roof (Pilamunga, 2021; Páez, 2020); hence, the aim of this research is to establish a comparative analysis between these types of industrial buildings.

The application of the finite element method allows finding approximations in the solution, since it divides the continuous medium of a domain into elements with finite dimensions, which supports the analysis of the structural response of a system (Nápoles et al., 2015). Regarding the application of this method, it is very useful to predict the performance and possible failures of a specific design; consequently, it will serve to obtain structures with greater benefits in safety, stability, and economy (Vásquez \& López, 2001).

\section{Materials and Methods}

The main objective of this research was to carry out a comparative analysis of the structural behavior between two flat and circular self-supporting roofs, using finite elements with the help of computer packages to determine the roof with the best structural performance when faced with the application of vertical and horizontal stresses.

\subsection{Description of self-supporting roofs}

In this research, two industrial buildings were considered that are made up of columns, truss-type perimeter beams and steel sheets as covering of the buildings, as can be seen in figure 1 ; it is worth mentioning that these structures lack of main beams and purlins. The free span that was used was $20 \mathrm{~m}$, and the separation between frames depended on the useful width of which each steel sheet is formed to create the self-supporting roof. Regarding the height of the columns 
of the sheds, they obeyed the type of shape that the roof received, i.e., both columns were raised in the circular shed to be equal in height, i.e., $6.00 \mathrm{~m}$; while on the flat roof, a minimum slope of $5 \%$ was applied (Fernández, 1998)height of its columns had to be different, i.e., height 1 was $6.00 \mathrm{~m}$ and height 2 was $6.70 \mathrm{~m}$.

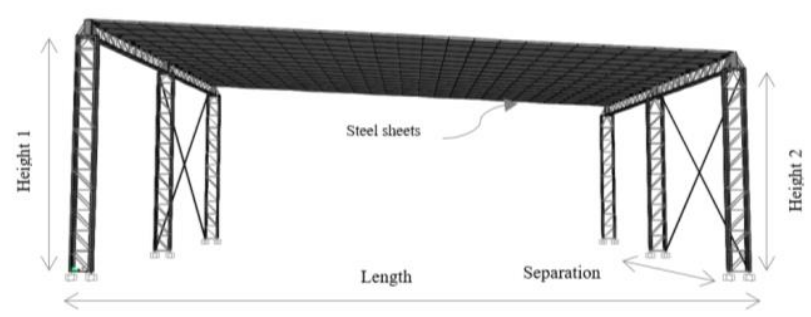

(a)

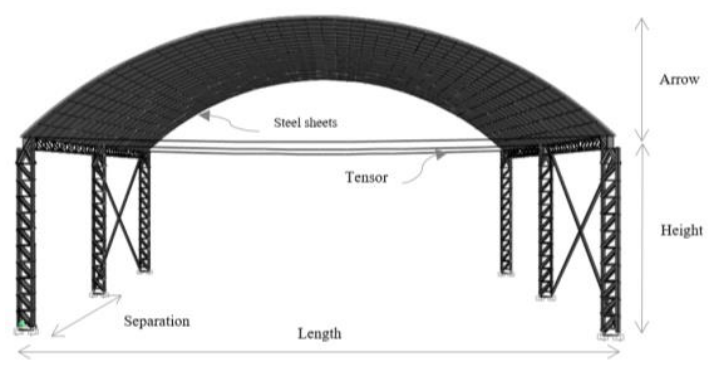

(b)

Figure 1. Self-supporting roofs geometry: a) flat, b) circular.

1.2. Characteristics of the material used in beams, columns, and steel sheet for selfsupporting roofs

For the configuration of the truss-type columns and perimeter beams, hot-rolled profiles were used, which had equal side angles (AISC, 2016), and cold-formed profiles type "C" or channels (AISI, 2016); thus, in this research ASTM A36 steel was used.

For the coverage of the sheds in this research, the Imap-800 sheet (Açoport, 2021), CS 1000-610 (Sanxing, 2021) was used for flat and circular roof respectively. Each of these has a different useful width, height and thickness recommended for the $20 \mathrm{~m}$ span, as shown in table 1 and figure 2.

Table 1. General characteristics of self-supporting roofs: flat and circular.

\begin{tabular}{ccccc}
\hline Roof type & Designation & $\begin{array}{c}\text { Width } \\
(\mathrm{mm})\end{array}$ & $\begin{array}{c}\text { Height } \\
(\mathrm{mm})\end{array}$ & $\begin{array}{c}\text { Recommended } \\
\text { thickness } \\
(\mathrm{mm})\end{array}$ \\
\hline Flat & Imap-800 & 800 & 260 & 1.55 \\
Circular & CS 1000-610 & 610 & 252 & 0.61 \\
\hline
\end{tabular}


REVISTA DE LA UNIVERSIDAD DEL ZULIA. 3épeca. Año $13 \mathrm{~N}^{\circ}$ 36, 2022

D. P. Guerrero-Cuasapaz et al. // Analysis of the structural behavior of flat and circular ... 222-240

DOI: http://dx.doi.org/10.46925//rdluz.36.15

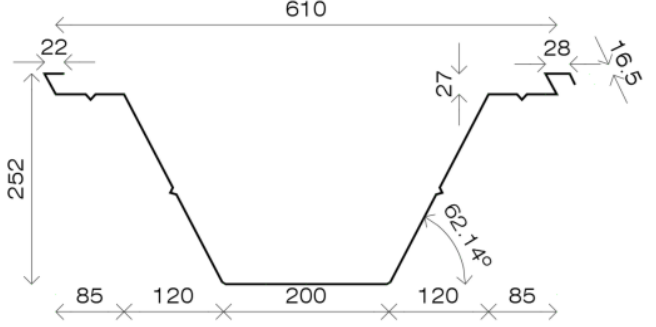

(a)

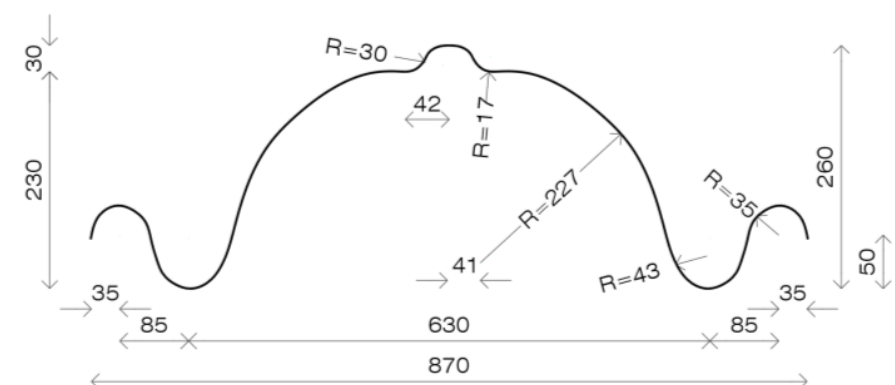

(b)

Figure 2. Steel sheets for self-supporting roofs: a) circular, b) flat.

The material used for the conformation of the self-supporting roofs comes from galvanized steel coils that lack of paint as indicated in the regulations (ASTM A653, 2020). Table 2 shows the technical sheet of the constituent material of the industrial buildings that were analyzed in this research.

Table 2. Technical data sheet of the material used in self-supporting roofs: flat and circular.

\begin{tabular}{lc}
\hline \multicolumn{1}{c}{ Description } & $\begin{array}{c}\text { Flat and } \\
\text { circular roof }\end{array}$ \\
\hline Coating designation & Z275-G90 \\
Coating weight on both sides $\left(\mathrm{g} / \mathrm{m}^{2}\right)$ & 275 \\
Base metal density $\left(\mathrm{kg} / \mathrm{m}^{3}\right)$ & 7850 \\
Young's modulus $\left(\mathrm{kg} / \mathrm{m}^{3}\right)$ & 200000 \\
Poisson's ratio & 0.3 \\
Bulk modulus $(\mathrm{MPa})$ & 167000 \\
Shear modulus $(\mathrm{MPa})$ & 76900 \\
Yield stress $(\mathrm{MPa})$ & 380 \\
Tensile strength $(\mathrm{MPa})$ & 480 \\
\hline
\end{tabular}

Additionally, it can be indicated as part of the specific geometry of the circular selfsupporting roof that the arrow used was $4.00 \mathrm{~m}$, which was determined through equations 1 (Ruiz, 2003) to 2 (Páez, 2020). 
REVISTA DE LA UNIVERSIDAD DEL ZULIA. 3época. Año 13 Nº 36, 2022

D. P. Guerrero-Cuasapaz et al. // Analysis of the structural behavior of flat and circular ... 222-240

DOI: http://dx.doi.org/10.46925//rdluz.36.15

$$
\begin{gathered}
R=\frac{L^{2}}{8 * f}+\frac{f}{2} \\
f=c * L
\end{gathered}
$$

Where " $\mathrm{R}$ " is the radius of the circumference of the self-supporting roof; " $\mathrm{L}$ " is the distance of the roof; " $F$ " is the arrow on the cover, and " $c$ " is a percentage that depends on the aesthetic or architectural environment; this value fluctuates between 0 to 50 \% (Proingcol, 2021). For this research, a percentage of $20 \%$ was used to generate a more economical roof, since the greater the deflection, the greater the length of the steel sheet, consequently, the greater weight of the steel.

In the flat self-supporting roof, a minimum slope indicated in the previous topics of this manuscript was used, as a consequence, the maximum height applied was $6.70 \mathrm{~m}$.

\subsection{Loads and load combinations applied to self-supporting roofs: flat and circular}

In this research, the loads applied to the self-supporting roofs were dead, live, hailstone, wind, and earthquake, i.e., vertical and horizontal loads.

The dead load corresponds to the own weight of the structural elements such as trusstype perimeter columns and beams and the so-called self-supporting steel sheets. Regarding the live load, it had a value of $70 \mathrm{~kg} / \mathrm{m}^{2}$ considered as an overload to carry out maintenance of the roof. The hailstone load on the circular self-supporting roof considered as a reference the slopes generated by the roof itself, less than $15 \%$ and less than $5 \%$, with the application of loads directed in the sense of gravity, which were $50 \mathrm{~kg} / \mathrm{m}^{2}$ and $100 \mathrm{~kg} / \mathrm{m}^{2}$ respectively; while in the flat self-supporting roof a value of $50 \mathrm{~kg} / \mathrm{m}^{2}$ was applied, being a representative value of a uniform accumulation of $5 \mathrm{~cm}$ of hailstone (NEC Cargas no sísmicas, 2014). The latter points out that the hailstone load application values are different due to the shape of the roofs and the possible accumulation of hailstone.

For the application of wind load in the analyzed structures, it is evident that it is due to the configuration presented in figure 1, i.e., a flat roof on one side and a circular roof on the other. It can be seen in figure 3 how the application diagrams are different. 


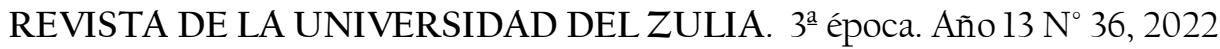

D. P. Guerrero-Cuasapaz et al. // Analysis of the structural behavior of flat and circular ... 222-240

DOI: http://dx.doi.org/10.46925//rdluz.36.15

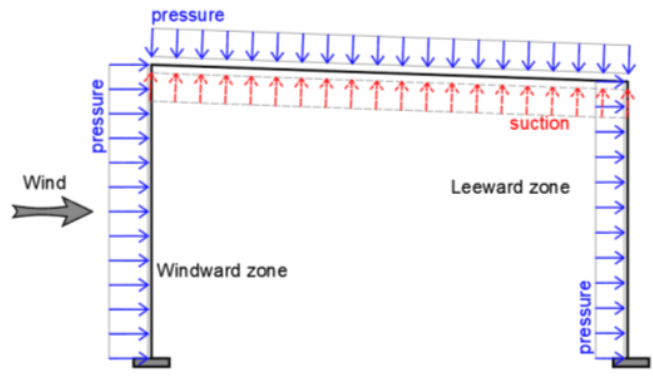

(a)

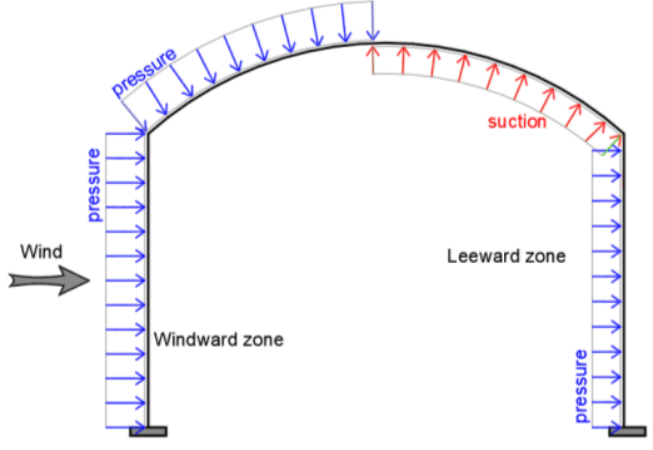

(b)

Figure 3. Wind load application diagrams on self-supporting roofs: a) flat, b) circular.

Because of the latter, tables 3 and 4 indicate the parameters used for the application of the wind load and table 5 shows the horizontal force due to the earthquake in industrial buildings.

Table 3. Parameters for wind load application on flat self-supporting roof.

\begin{tabular}{ccccccc}
\hline $\begin{array}{c}\text { Length } \\
(\mathrm{m})\end{array}$ & $\begin{array}{c}\text { Cover } \\
\text { height } \\
(\mathrm{m})\end{array}$ & $\mathrm{C}_{1}$ & $\mathrm{C}_{2}$ & $\begin{array}{c}\mathrm{V}_{\mathrm{b}} \\
(\mathrm{km} / \mathrm{h})\end{array}$ & $\begin{array}{c}\text { W.P. } \\
\left(\mathrm{kg} / \mathrm{m}^{2}\right)\end{array}$ & $\begin{array}{c}\text { L.P. } \\
\left(\mathrm{kg} / \mathrm{m}^{2}\right)\end{array}$ \\
\hline 20 & 7.66 & 0.880 & 1.63 & 66.53 & 10.64 & 21.28 \\
\hline
\end{tabular}

$\mathrm{C}_{1}$ : height correction coefficient, $\mathrm{C}_{2}$ : height environment coefficient, $\mathrm{V}_{\mathrm{b}}$ : corrected wind speed, W.P.: windward pressure, L.P.: leeward pressure.

Table 4. Parameters for wind load application on circular self-supporting roof.

\begin{tabular}{ccccccc}
\hline $\begin{array}{c}\text { Length } \\
(\mathrm{m})\end{array}$ & $\begin{array}{c}\text { Cover } \\
\text { height } \\
(\mathrm{m})\end{array}$ & $\mathrm{C}_{1}$ & $\mathrm{C}_{2}$ & $\begin{array}{c}\mathrm{V}_{\mathrm{b}} \\
(\mathrm{km} / \mathrm{h})\end{array}$ & $\begin{array}{c}\text { W.P. } \\
\left(\mathrm{kg} / \mathrm{m}^{2}\right)\end{array}$ & $\begin{array}{c}\text { L.P. } \\
\left(\mathrm{kg} / \mathrm{m}^{2}\right)\end{array}$ \\
\hline 20 & 10.30 & 0.902 & 1.91 & 68.20 & 30.50 & 26.15 \\
\hline
\end{tabular}

$\mathrm{C}_{1}$ : height correction coefficient, $\mathrm{C}_{2}$ : height environment coefficient, $\mathrm{V}_{\mathrm{b}}$ : corrected wind speed, W.P.: windward pressure, L.P.: leeward pressure.

In this paper, analysis and design of the self-supporting roofs were carried out using the method by load and resistance factor design with its acronym LRFD, in which the resistance or failure condition is considered and where the applied service loads of the structure is factored 
REVISTA DE LA UNIVERSIDAD DEL ZULIA. 3épeca. Año $13 \mathrm{~N}^{\circ}$ 36, 2022

D. P. Guerrero-Cuasapaz et al. // Analysis of the structural behavior of flat and circular ... 222-240

DOI: http://dx.doi.org/10.46925//rdluz.36.15

and also the resistance of the material is reduced. This factored load must be less than or equal to the reduced resistance (Loachamin et al., 2021); for this purpose, a computational package that works with finite elements was used (SAP 2000, 2021).

Table 5. Parameters to define the basal shear used in self-supporting roofs: flat and circular.

\begin{tabular}{lcc}
\hline Description & Parameter & Value \\
\hline Importance factor & $\mathrm{I}$ & 1.00 \\
Seismic force reduction factor & $\mathrm{R}$ & 3.00 \\
Seismic zone & - & $\mathrm{V}$ \\
Zone acceleration factor & $\mathrm{Z}$ & 0.40 \\
Spectral amplification ratio & $\mathrm{\eta}$ & 2.48 \\
Soil type & - & $\mathrm{C}$ \\
$\mathrm{F}_{\mathrm{a}}$ site fact & $\mathrm{F}_{\mathrm{a}}$ & 1.20 \\
$\mathrm{~F}_{\mathrm{d}}$ site fact & $\mathrm{F}_{\mathrm{d}}$ & 1.11 \\
$\mathrm{~F}_{\mathrm{s}}$ inelastic behavior factor of the soil & $\mathrm{F}_{\mathrm{s}}$ & 1.11 \\
Project geographic location factor & $\mathrm{r}$ & 1.00 \\
Limit period in $\mathrm{T}=\mathrm{T}_{\mathrm{o}}$ & $\mathrm{T}_{\mathrm{o}}(\mathrm{s})$ & 0.103 \\
Limit period in $\mathrm{T}=\mathrm{T}_{\mathrm{c}}$ & $\mathrm{T}_{\mathrm{c}}(\mathrm{s})$ & 0.565 \\
Limit period in $\mathrm{T}=\mathrm{T}_{\mathrm{l}}$ & $\mathrm{T}_{\mathrm{l}}(\mathrm{s})$ & 2.664 \\
Plant irregularity factor & $\phi_{\mathrm{P}}$ & 1.00 \\
Elevation irregularity factor & $\phi_{\mathrm{E}}$ & 1.00 \\
Basal shear with respect to reactive load & $\mathrm{V}$ & 0.3968 \\
\hline
\end{tabular}

The load combinations used in this research are those detailed in equations 3 to 10 (NEC Cargas no sísmicas, 2014).

Where "D" is the dead load; "L" corresponds to live load; "Lr" is the live roof load, "S" represents the hail load; "W" corresponds to the wind load; "E" represents the load due to earthquake.

After the analysis and design (SAP 2000, 2021), the structure was discretized and only the steel sheets with the cross-section indicated in figure 2 were taken into consideration for selfsupporting roofs: flat and circular, in which the computational tool for analysis and simulation by finite elements (ANSYS, 2021) was used, in which the self-supporting roofs were modeled. 
The modeling of 9 steel sheets was proposed for the circular self-supporting roof, while 15 steel sheets were used in the roof in the flat for modeling, as indicated in figures 4 and 5.

$$
\begin{gathered}
U_{1}=1.4 D \\
U_{2}=1.2 D+1.6 L+0.5 \max (\operatorname{Lr}, S) \\
U_{3}=1.2 D+1.6 \max (\operatorname{Lr}, S) \\
+\max (L, 0.5 W(+,-)) \\
U_{4}=1.2 D+W(+,-)+L \\
+0.5 \max (L r, S) \\
U_{5}=1.2 D+E(x(+,-), y(+,-))+L \\
+0.2 S \\
U_{6}=0.9 D+W(+,-) \\
U_{7}=0.9 D+E(x(+,-), y(+,-)) \\
U_{8}=D+L
\end{gathered}
$$

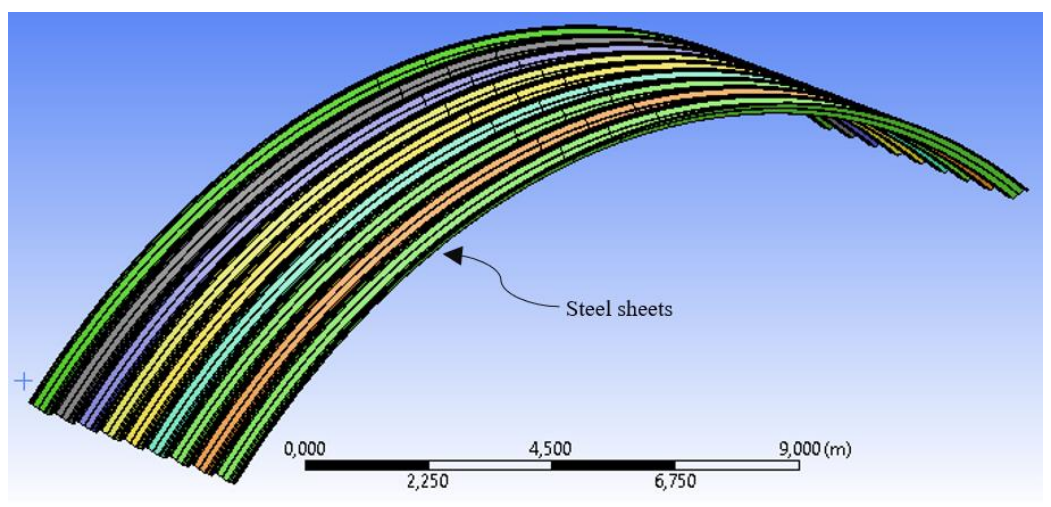

Figure 4. Steel sheets for circular self-supporting roof. 


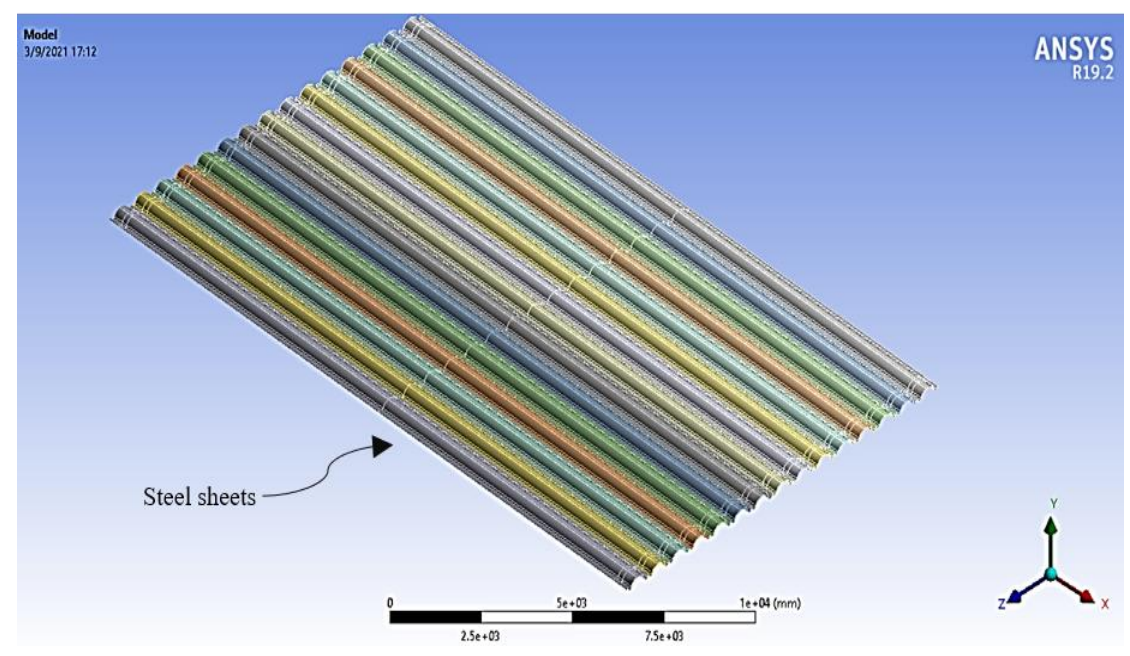

Figure 5. Steel sheets for flat self-supporting roof.

Regarding the analysis of the simulation by finite elements (ANSYS, 2021), in the selfsupporting roofs: flat and circular for the discretization of the steel sheets, surface bodies were used due to the small thicknesses indicated in table 1, i.e., these elements have their nodes located at their vertices. This alternative was chosen due to the less computational time generated in it; these surface bodies that were used were triangular and quadrilateral elements (Lee, 2019), as seen in figures 6 and 7.

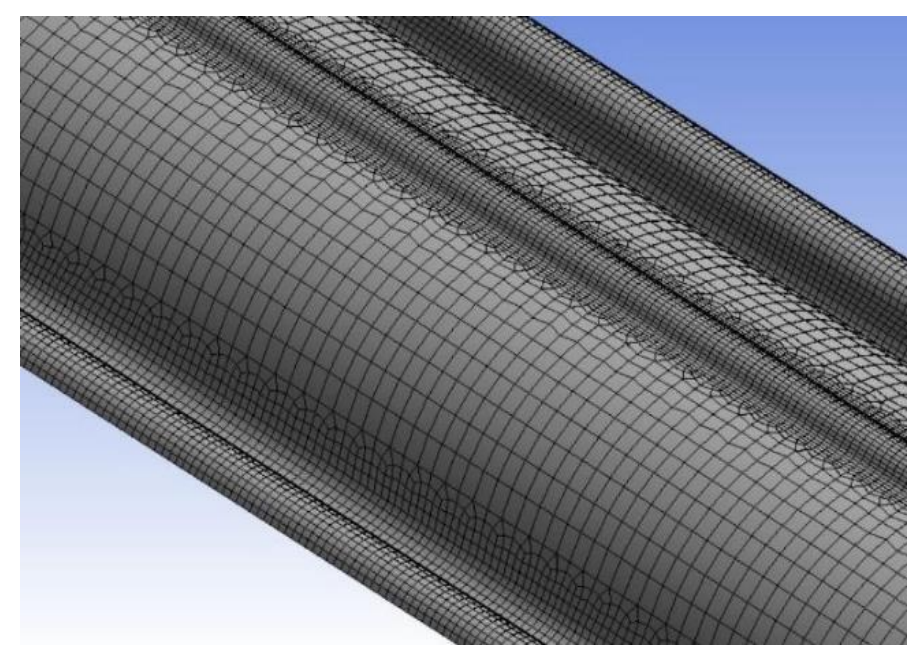

Figure 6. Discretization of flat self-supporting roof. 


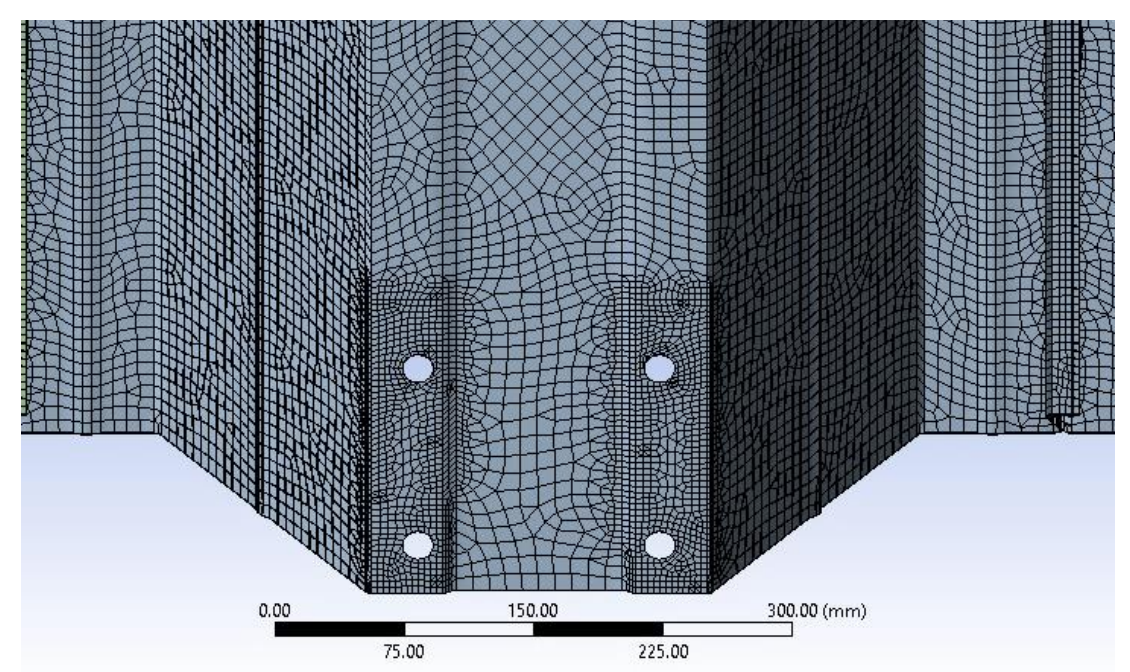

Figure 7. Discretization of circular self-supporting roof.

The supports that were applied in the circular self-supporting roof were an edge condition without displacements as can be seen in figure 8 but allowing rotations; in addition, the interaction that existed between the steel sheets with the clamping plates were taken into account. This is a vertical displacement restriction on the surfaces that are in direct contact with the support plate, and the same edge condition was applied in the flat self-supporting roof (Páez, 2020; Pilamunga, 2021).

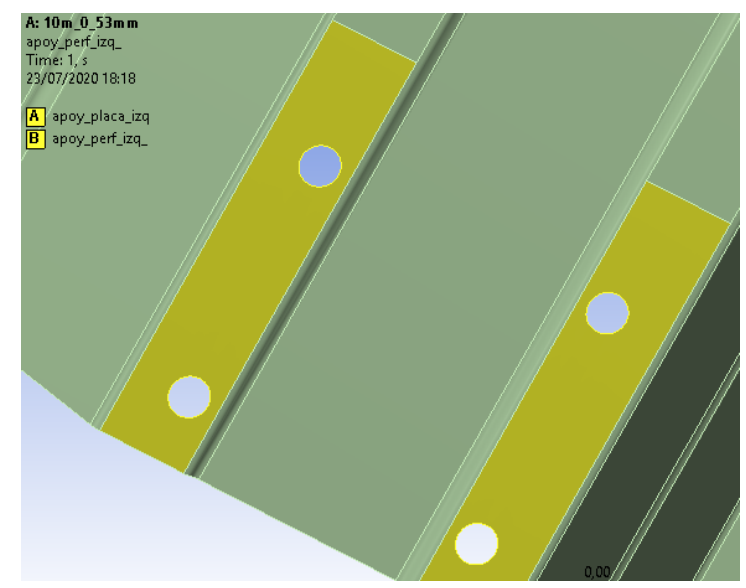

(a)

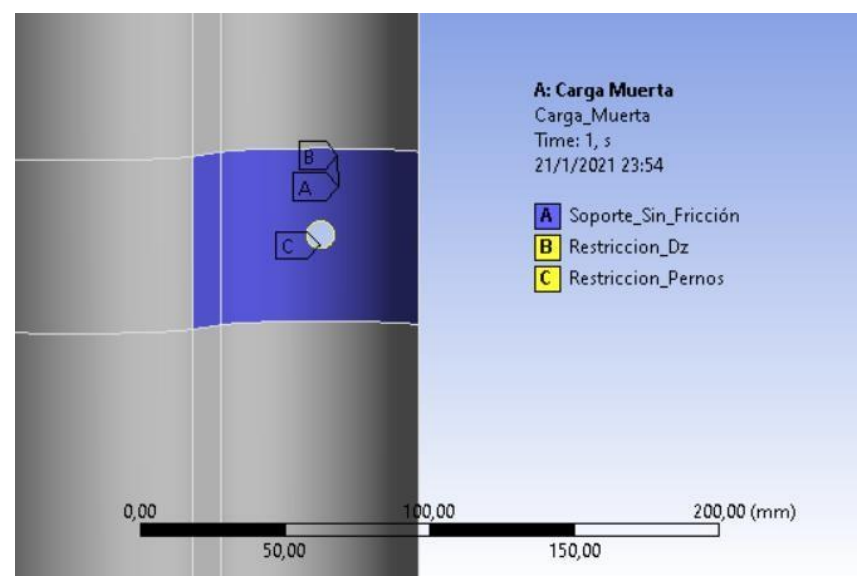

(b)

Figure 8. Edge condition in self-supporting roofs: a) circular, b) flat. 
REVISTA DE LA UNIVERSIDAD DEL ZULIA. 3época. Año 13 Nº 36, 2022

D. P. Guerrero-Cuasapaz et al. // Analysis of the structural behavior of flat and circular ... 222-240

DOI: http://dx.doi.org/10.46925//rdluz.36.15

\section{Results and Discussions}

Due to the complexity of the cross-sections of the steel sheets used for flat and circular self-supporting roofs, an equivalent thickness was used as shown in table 6; these were modeled in a computer package (SAP 2000, 2021), which served as starting point to analyze the complete structure, consisting of structural elements such as columns, beams, and steel sheets.

Table 6. Equivalent thickness of self-supporting roofs.

\begin{tabular}{cc}
\hline Roof type & $\begin{array}{c}\text { Equivalent thickness } \\
(\mathrm{mm})\end{array}$ \\
\hline Flat & 60.91 \\
Circular & 50.70 \\
\hline
\end{tabular}

Analysis and design of the elements that make up the industrial buildings were carried out using steel sheets for flat and circular roofs; tables 7 to 10 show axial loads and displacements for certain load combinations indicated in the equations described in the previous section of this manuscript. The reactions were taken from the zone with the largest tributary area; additionally, the displacements were extracted in the upper part of the left and right column, both for the flat and circular self-supporting roof. Table $\mathrm{ll}$ shows the behavior of the structures concerning vibration modes and periods (SAP 2000, 2021), for both self-supporting roofs.

Table 7. Flat self-supporting roof reactions.

\begin{tabular}{ccccc}
\hline \multicolumn{5}{c}{ Reactions (kgf) } \\
Load pattern & D & L & D+L & $1.2 \mathrm{D}+1.6 \mathrm{~L}$ \\
\hline Left column & 1646.70 & 262.91 & 1909.61 & 2396.70 \\
Right column & 1656.86 & 269.29 & 1926.14 & 2419.08 \\
\hline
\end{tabular}

In the tables presented above, it is evident that concerning the reactions for a combination of dead load plus live load, the circular self-supporting roof transmitted greater load, and this corresponds to 2.24 times the value of the load transmitted by the self-supporting 
REVISTA DE LA UNIVERSIDAD DEL ZULIA. 3épeca. Año $13 \mathrm{~N}^{\circ}$ 36, 2022

D. P. Guerrero-Cuasapaz et al. // Analysis of the structural behavior of flat and circular ... 222-240

DOI: http://dx.doi.org/10.46925//rdluz.36.15

roof in the flat; consequently, structural elements such as columns of the circular self-supporting roof were found with higher axial loads.

Table 8. Displacements of flat self-supporting roof.

\begin{tabular}{ccccccc}
\hline \multirow{2}{*}{ Load pattern } & \multicolumn{3}{c}{ Left column } & \multicolumn{2}{c}{ Right column } & \multicolumn{2}{c}{ Center of span } \\
& & Seismic & & Seismic & & \\
& Seismic X & Y & Seismic X & Y & D & D+L \\
\hline Direction X & 11.81837 & 0.02099 & 11.81232 & 0.02174 & -3.24299 & -3.88444 \\
Direction Y & 0.01579 & 4.81941 & 0.02903 & 3.1696 & -0.00217 & -0.00229 \\
Direction Z & 0.03891 & 0.13525 & 0.0831 & 0.08181 & -54.0214 & -64.61017 \\
\hline
\end{tabular}

Table 9. Circular self-supporting roof reactions.

\begin{tabular}{ccccc}
\hline \multicolumn{5}{c}{ Reactions (kgf) } \\
Load pattern & D & L & D+L & $1.2 \mathrm{D}+1.6 \mathrm{~L}$ \\
\hline Left column & 845.97 & 3466.26 & 4312.25 & 6561.20 \\
Right column & 846.00 & 3466.64 & 4312.64 & 6561.82 \\
\hline
\end{tabular}

Table 10. Displacements of circular self-supporting roof.

\begin{tabular}{ccccccc}
\hline \multirow{2}{*}{ Load pattern } & \multicolumn{3}{c}{ Left column } & \multicolumn{2}{c}{ Right column } & \multicolumn{2}{c}{ Center of span } \\
& & Seismic & & Seismic & & \\
& Seismic X & Y & Seismic X & Y & D & D+L \\
\hline Direction X & 10.14669 & 0.62355 & 10.14891 & -0.56252 & -0.00169 & -0.01378 \\
Direction Y & 0.01279 & 1.10895 & 0.01278 & 1.10295 & 0.0007009 & 0.00348 \\
Direction Z & -0.06678 & 0.06323 & 0.6676 & -0.06251 & -6.4048 & -34.6591 \\
\hline
\end{tabular}

Table 11. Vibration modes and periods in self-supporting roofs: flat and circular.

\begin{tabular}{ccc}
\hline & $\begin{array}{c}\text { Flat } \\
\text { cover } \\
\text { Meriod (s) }\end{array}$ & $\begin{array}{c}\text { Circular } \\
\text { cover } \\
\text { Period (s) }\end{array}$ \\
\hline 1 & 0.419204 & 0.322233 \\
2 & 0.34656 & 0.314963 \\
3 & 0.218914 & 0.243651 \\
\hline
\end{tabular}


REVISTA DE LA UNIVERSIDAD DEL ZULIA. 3épeca. Año $13 \mathrm{~N}^{\circ}$ 36, 2022 D. P. Guerrero-Cuasapaz et al. // Analysis of the structural behavior of flat and circular ... 222-240

DOI: http://dx.doi.org/10.46925//rdluz.36.15

On the other hand, about the displacements under the same combination described in the previous paragraph, it was found that the displacement in the direction of gravity for the circular self-supporting roof corresponds to $53.64 \%$ of the value found for the flat selfsupporting roof; consequently, the circular roof has a lower deflection located in the center of the span.

Regarding the seismic behavior of industrial buildings, it was observed that the vibration modes and periods of each of the analyzed structures comply with the provisions of the Ecuadorian Construction Standard in the chapter corresponding to seismic danger, which indicates that the fundamental period of vibration corresponds to an estimate of the value of the period of the structure, which allows finding the horizontal forces due to earthquakes applied to the structure (NEC Peligro sísmico, 2014), applying equation 11.

$$
T=C_{t} * h_{n}^{\alpha}
$$

Where " $\mathrm{T}$ " is the period of vibration of the structure, " $\mathrm{C}_{t}$ " is the coefficient that depends on the type of structure. For this investigation a value of 0.073 was taken, which represents a steel structure with bracing. Additionally, as a consequence of this value, the coefficient " $\alpha$ " was considered with a value of 0.75 and in turn this depends on the type of structure, " $h_{n}$ " is the maximum height of the structure measured from the base in meters. If the value obtained from the period found with equation 11 is increased by $30 \%$, this value constitutes the period of vibration calculated analytically according to (NEC Peligro sísmico, 2014); therefore, the period of vibration found with a modal analysis (SAP 2000, 2021) should not exceed the calculated analytically, as can be seen in table 12 .

Table 12. Calculated vibration period of self-supporting roofs: flat and circular.

\begin{tabular}{ccc}
\hline Roof type & $\begin{array}{l}\mathrm{T}_{\mathrm{ma}} \\
(\mathrm{s})\end{array}$ & $\begin{array}{c}\mathrm{T}_{\mathrm{a}} \\
(\mathrm{s})\end{array}$ \\
\cline { 2 - 4 } $\mathrm{T}_{\mathrm{ma}}$ : vibration period of & 0.4192 & 0.4368 \\
Circular & 0.3222 & 0.5456 \\
\cline { 2 - 3 }
\end{tabular}




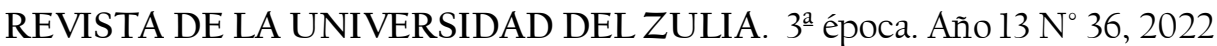

D. P. Guerrero-Cuasapaz et al. // Analysis of the structural behavior of flat and circular ... 222-240

DOI: http://dx.doi.org/10.46925//rdluz.36.15

Analyzing tables 11 and 12 it is observed that the period found by the modal analysis corresponds to a lower value than that calculated analytically, consequently, both selfsupporting roofs comply with what is indicated in the Ecuadorian Construction Standard,seismic danger chapter.

Table 13 shows the inelastic drifts in the $\mathrm{X}$ and $\mathrm{Y}$ directions. It can be seen that the drifts obtained from the structural analysis did not exceed the value of the maximum inelastic drift corresponding to 0.02 (NEC Peligro sísmico, 2014), calculated as indicated in equation 12.

$$
\Delta_{i}=0.75 * R * \Delta_{e}
$$

Where " $\Delta_{\mathrm{i}}$ " is the maximum inelastic drift, "R" corresponds to the response reduction factor and " $\Delta_{\mathrm{e}}$ " corresponds to the relation between displacement and height.

Table 13. Inelastic drifts of self-supporting roofs.

\begin{tabular}{cccc}
\hline Roof type & $\Delta_{\mathrm{x}}$ & $\Delta_{\mathrm{y}}$ & $\Delta_{\mathrm{i}}$ \\
\hline Flat & 0.004109 & 0.001559 & 0.02 \\
Circular & 0.002907 & 0.000883 & 0.02 \\
\hline
\end{tabular}

$\Delta_{\mathrm{x}}$ : inelastic drift in direction " $\mathrm{x}$ ", $\Delta_{\mathrm{y}}$ : inelastic drift in direction " $\mathrm{y}$ ", $\Delta_{\mathrm{i}}$ : maximum inelastic drift.

Another very important piece of data within the field of design and construction which directly affects the cost of steel corresponds to the weight index of the structure over the area of the industrial buildings, as can be seen in table 14. The index of the circular self-supporting roof is less than the flat roof, i.e., the total weight in the circular self-supporting roof corresponds to $56 \%$ of the corresponding value in the flat self-supporting roof.

Table 14. Weight index on self-supporting roof area: flat and circular.

\begin{tabular}{cccc}
\hline Roof type & $\begin{array}{c}\text { Steel sheet } \\
\text { weight } \\
\left(\mathrm{kg} / \mathrm{m}^{2}\right)\end{array}$ & $\begin{array}{c}\text { Beams and columns } \\
\text { weight } \\
\left(\mathrm{kg} / \mathrm{m}^{2}\right)\end{array}$ & $\begin{array}{c}\text { Total weight } \\
\left(\mathrm{kg} / \mathrm{m}^{2}\right)\end{array}$ \\
\hline Flat & 21.85 & 8.76 & 30.61 \\
Circular & 11.00 & 6.16 & 17.16 \\
\hline
\end{tabular}


REVISTA DE LA UNIVERSIDAD DEL ZULIA. 3época. Año 13 Nº 36, 2022 D. P. Guerrero-Cuasapaz et al. // Analysis of the structural behavior of flat and circular ... 222-240

DOI: http://dx.doi.org/10.46925//rdluz.36.15

Regarding the modeling used (ANSYS, 2021), and considering figures 6 and 7, in table 15 it is possible to observe the number of elements and nodes in which the self-supporting roofs were discretized, in which it could be seen that the number of nodes and elements of the flat self-supporting roof corresponds to a value of $50 \%$ of that obtained for a circular self-supporting roof.

Table 15. Number of nodes and elements in self-supporting roofs: flat and circular.

\begin{tabular}{cccc}
\hline Roof type & $\begin{array}{c}\text { Steel sheet } \\
\text { quantity }\end{array}$ & $\begin{array}{c}\text { Node } \\
\text { quantity }\end{array}$ & $\begin{array}{c}\text { Elements } \\
\text { quantity }\end{array}$ \\
\hline Flat & 15 & 869164 & 853834 \\
Circular & 9 & 1706600 & 1985400 \\
\hline
\end{tabular}

In the finite element simulation process, in order to comply with what is related to the stresses and displacements obtained in the industrial buildings, the thickness of the steel sheets that made up the self-supporting roofs was increased, as indicated in table 16, being the allowable limit value in creep $342 \mathrm{MPa}$ and the allowable limit displacement of $100 \mathrm{~mm}$. It was observed that stresses and displacements on both roofs are fully met with these parameters; additionally, it was observed that the greatest stresses were presented at the supports of each roof as shown in figure 9, i.e., at the ends; while the maximum displacements were presented in the center of the span of each roof as shown in figure 10.

Table 16. Maximum stresses and displacements in self-supporting roofs.

\begin{tabular}{ccccc}
\hline $\begin{array}{c}\text { Roof } \\
\text { type }\end{array}$ & $\begin{array}{c}\text { Initial } \\
\text { thickness } \\
(\mathrm{mm})\end{array}$ & $\begin{array}{c}\text { Final } \\
\text { thickness } \\
(\mathrm{mm})\end{array}$ & $\begin{array}{c}\text { Maximum } \\
\text { stress } \\
(\mathrm{MPa})\end{array}$ & $\begin{array}{c}\text { Maximum } \\
\text { displacement } \\
(\mathrm{mm})\end{array}$ \\
\hline Flat & 1.55 & 1.95 & 330.19 & 89.273 \\
Circular & 0.61 & 0.76 & 272.42 & 12.785 \\
\hline
\end{tabular}




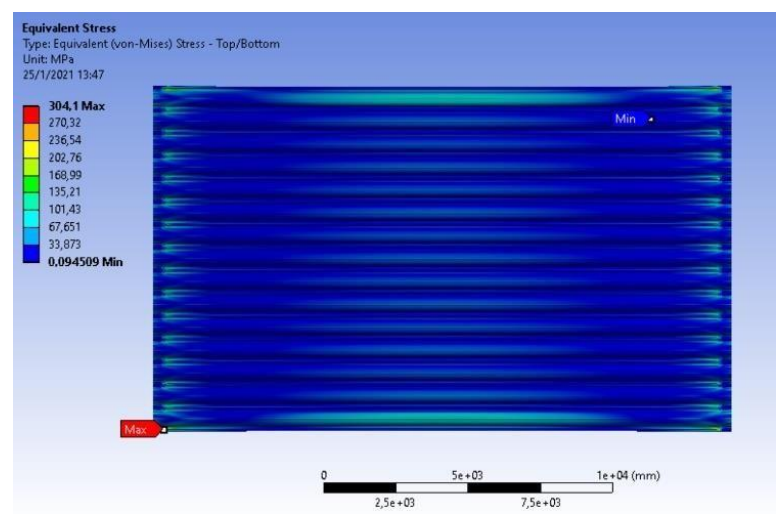

(a)

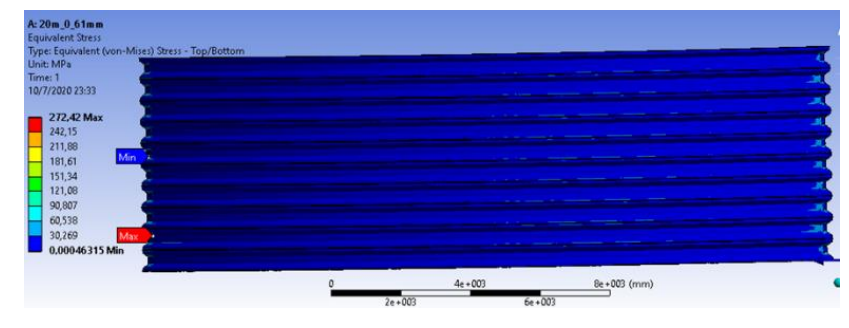

(b)

Figure 9. Maximum stresses in self-supporting roofs: a) flat, b) circular.

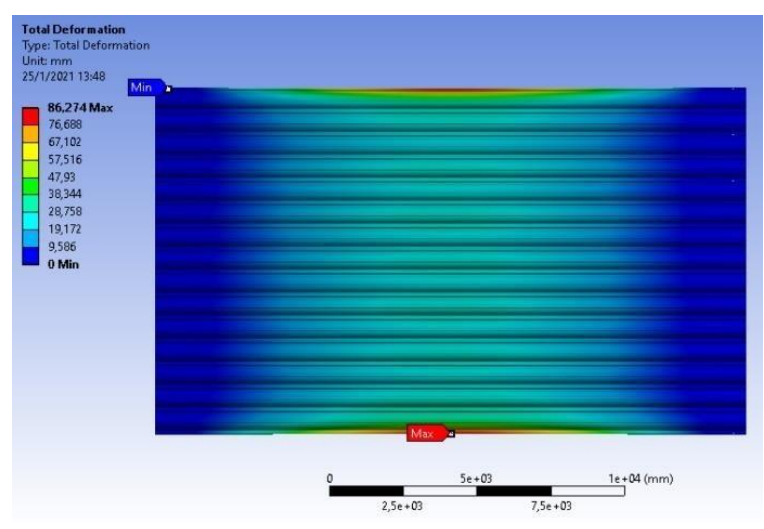

(a)

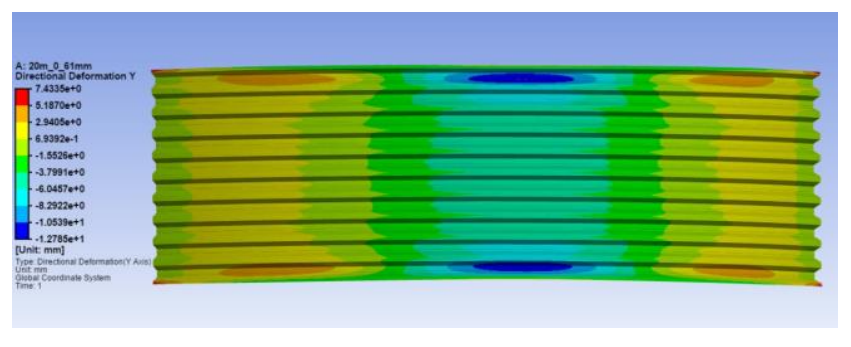

(b)

Figure 10. Maximum displacements in self-supporting roofs: a) flat, b) circular.

\section{Conclusions}

In this research, when analyzing the structures corresponding to self-supporting roofs: flat and circular with the characteristics described in this manuscript it can be concluded that the circular self-supporting roof provides better benefits in terms of structural behavior, i.e., both the efforts and displacements generated by the application of horizontal and vertical 


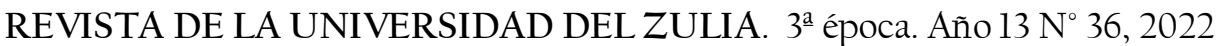
D. P. Guerrero-Cuasapaz et al. // Analysis of the structural behavior of flat and circular ... 222-240 DOI: http://dx.doi.org/10.46925//rdluz.36.15

stresses easily comply with the parameters established within the Ecuadorian Construction Standard.

After the analysis and structural design, it is very important to mention that the weight of the steel sheets that make up the circular self-supporting roof was less in the construction area than the sheets that make up the flat self-supporting roof; consequently, this factor will greatly influence in deciding to choose any of the alternatives (flat and circular) for the application in a certain project.

\section{References}

Açoport (2021). Açoport Telhas Autoportantes. http://acoport.com.br/telhas-autoportantes/dadostecnicos/

AISC (2016). Specification for Structural Steel Buildings Supersedes the Specification for Structural Steel Buildings dated and all previous versions Approved by the Committee on Specifications.

AISI (2016). North American Specification for the Design of Cold-Formed Steel Structural Membe (N. . 2016). 1-505. https://cfsei.memberclicks.net/assets/docs/publications/aisi-standards/aisi s100-16 s10016-c_e_s.pdf

ANSYS (2021). Ansys Academic | Simulation Software for Educators, Researchers and Students. https://www.ansys.com/academic

Arnedo Pena, A. (2016). Naves industriales con acero. Sener, 97. www.sener.es

ASTM A653 (2020). ASTM A653 / A653M - 20 Standard Specification for Steel Sheet, Zinc-Coated (Galvanized) or Zinc-Iron Alloy-Coated (Galvannealed) by the Hot-Dip Process. https://www.astm.org/Standards/A653.htm

Cuichán Velasco, A. S., \& Escuela Politécnica Nacional (2016). Análisis y diseño de una nave industrial y sus respectivas fosas dentro del taller "Chiriyacu» para ferrocarriles del Ecuador Empresa Pública F.E.E.P.

Durma (2016). Las cubiertas autoportantes y sus características - Estructuras Metálicas. https:/www.durmametal.com/las-cubiertas-autoportantes-caracteristicas/

Fernández Madrid, J. (1998). La cubierta plana. Tectónica: monografías de arquitectura, tecnología y construcción, 6, 1-16.

Lee, H. H. (2019). Finite element simulation with ANSYS Workbench 2019 (SDC Publications (ed.); Primera ed). 
REVISTA DE LA UNIVERSIDAD DEL ZULIA. 3época. Año 13 Nº 36, 2022 D. P. Guerrero-Cuasapaz et al. // Analysis of the structural behavior of flat and circular ... 222-240 DOI: http://dx.doi.org/10.46925//rdluz.36.15

Loachamin Chano, D. F., Freire Luna, A. E., Guerrero Cuasapaz, D. P., \& Guerrón Figueroa, M. B. (2021). Análisis técnico-económico de naves industriales mediante interpolación no lineal de Lagrange. Revista Técnica de la Facultad de Ingeniería Universidad Del Zulia, 44(2), 1-15. https://doi.org/https://doi.org/10.22209/rt.v44n2a05

Nápoles Padrón, E., González Carbonell, R., \& Olivares Díaz, E. (2015). Una introducción al análisis por elementos finitos: aplicaciones y ejemplos (E. Piñero de Laosa (ed.); Primera). Editorial Universitaria. https://www.researchgate.net/publication/283151622

NEC Cargas no sísmicas (2014). Cargas no sísmicas. Norma Ecuatoriana de la Construcción, 1-44.

NEC Peligro sísmico (2014). Peligro sísmico. Norma Ecuatoriana de la Construcción, 1-148.

Páez Redrován, C. D., \& Universidad Politécnica Salesiana (2020). Método de elementos finitos aplicado a cubiertas autoportantes tipo circular. En Tesis. Universidad Politécnica Salesiana.

Pilamunga Guallpa, J. L., \& Universidad Politécnica Salesiana (2021). Simulación de una cubierta plana autoportante y su conexión con las vigas laterales mediante la aplicación de elementos finitos. En Tesis. Universidad Politécnica Salesiana.

Proingcol (2021). Cubiertas autoportantes - Proing LTDA | Manlift \& Cubiertas autoportantes. https://proingcol.co/cubiertas-autoportantes/

Ruiz Sancho, J. M. (2003). Geometria análitica del plano y del espacio (Anaya Educación (ed.); 2003. ${ }^{2}$ ed.).

Sanxing (2021). Yingkou Sanxing Roll Forming Machine Co., Ltd. - Building Material Machinery. https://yk-sanxing.en.alibaba.com/

SAP 2000. (2021). SAP2000 | STRUCTURAL ANALYSIS AND DESIGN. https://www.csiamerica.com/products/sap2000

Soria Carrasco, H. D., \& Escuela Politécnica Nacional (2020). Análisis tecno económico entre galpones con cubiertas autoportantes y cubiertas a dos aguas con luces de 20 metros fabricadas en acero estructural. Escuela Politécnica Nacional.

Vásquez, M., \& López, E. (2001). El método de los elementos finitos aplicado al análisis estructural (Noela-Madrid (ed.); Primera). https://www.academia.edu/38827344/El_método_de_los_Elementos_Finitos_aplicado_al_anális is_estructural_Manuel_Vázquez_Eloísa_López 